\title{
Redescription of the feather mite Gabucinia delibata (Robin, 1877) (Astigmata: Gabuciniidae), newly recorded from the hooded crow, Corvus cornix (Linnaeus, 1758) (Passeriformes: Corvidae) in Egypt
}

\author{
Mohamed Waleed Negm ${ }^{1 *}$ (D) and Hassan Mohamed Hassan²
}

\begin{abstract}
Background: Faunistic information about feather mites in Egypt is scarce, as well as in the Middle East region. Results: Gabucinia delibata (Robin, 1877) (Astigmata: Pterolichoidea: Gabuciniidae) is recorded for the first time in Egypt from the hooded crow, Corvus cornix (Linnaeus, 1758) (Passeriformes: Corvidae). Adult males and females of $G$. delibata are redescribed and illustrated. Examined specimens were compared with previous description and anomalous features were discussed.
\end{abstract}

Conclusion: The new mite record reported here provides descriptive information for future taxonomic research of feather mites in Egypt. Hopefully, the present work would encourage more comprehensive surveys in the Middle East region since a large number of undiscovered species is expected.

Keywords: Acari, Feather mites, Gabucinia delibata, Corvidae, Egypt

\section{Background}

Feather mites of the superfamilies Pterolichoidea and Analgoidea (Acari: Astigmata) are bird ectoparasites and commensals, mostly harboring the ventral surface of flight feathers (Gaud \& Atyeo, 1996; Mironov, Proctor, Barreto, \& Zimmerman, 2007). The feather mite genus Gabucinia Oudemans, 1905 was originally described in the content of the family Pterolichidae Trouessart and Mégnin, 1884. Afterwards, Gaud and Atyeo (1974) removed Gabucinia from Pterolichidae to a newly established family Gabuciniidae with 13 genera, of which 11 were established as new. The family Gabuciniidae currently includes about 60 species in 16 genera (De Alzuet, Cicchino, \& Abrahamovich, 1988; Gaud, 1978, 1983; Gaud \& Atyeo, 1974; Mironov \& Galloway, 2003; Mironov, Literak, Sychra, \& Capek, 2014; Proctor, Zimmerman, \& Meyer, 2006). Gabuciniid mites

\footnotetext{
* Correspondence: waleednegm@yahoo.com

${ }^{1}$ Department of Plant Protection, Faculty of Agriculture, Assiut University, Assiut 71526, Egypt

Full list of author information is available at the end of the article
}

clearly differ from other pterolichoids in having the following features: (i) in both sexes, seta $k T$ on tibia IV is absent; (ii) in females, the genital papillae (discs of some previous authors) are situated posterior to setae $g$ and the oviporus; (iii) the opisthosoma of males with two opisthosomal lobes; and (iv) in males, the genital organ is distant from setae $g$ and situated usually posterior to level of trochanters IV (Gaud \& Atyeo, 1974, 1996). Main diagnostic features for all currently recognized genera of Gabuciniidae were provided by Mironov et al. (2007); the latest key to genera was provided by Gaud and Atyeo (1996).

Faunistic information about feather mites in Egypt is scarce, as well as for other Middle Eastern countries. In Egypt, the first extensive survey of the feather mite fauna was done by Rakha (1980), reporting 62 species within 14 families. Subsequently, some faunistic studies have been conducted (Abd-Alla, 1993; El-Bishlawy \& Oyoun, 1989; Mahgoob, Tharwat, Kilany, \& Hafez, 2006; Mazyad, Morsy, Fekry, \& Farrag, 1999; Mohamed, 1994; Morsy, Mazyad, \& Younis, 1999; Negm, Mohamed, El-Gepaly, \& 
Abdelaziz, 2018; Rakha \& Mohamed, 1980; Shoker, Tawfek, Ibrahim, \& Osman, 2001; Zaher \& Rakha, 1981). In neighboring countries, few studies have been also conducted in the past 60 years, of these Gaud (1958) in Morocco, Mohamed (1994) in Yemen, and Negm, Nasser, Alatawi, Al Ahmad, and Shobrak (2013) and Negm, Hernandes, Nasser, Al Ahmad, and Shobrak (2019) in Saudi Arabia.

Although the hooded crow, Corvus cornix (Linnaeus, 1758) (Passeriformes: Corvidae) is of common and widespread occurrence in Egypt, previous studies on Egyptian feather mites showed no indication for the presence of Gabucinia delibata (Robin, 1877), a widely distributed gabuciniid mite associated with corvids (Canestrini \& Kramer, 1899; Galloway, Proctor, \& Mironov, 2014; Gaud \& Atyeo, 1974; Gaud \& Till, 1961; Mironov, 1996). Since the latest illustration and description of this mite given in the middle of the 1970s, therefore, we presumed

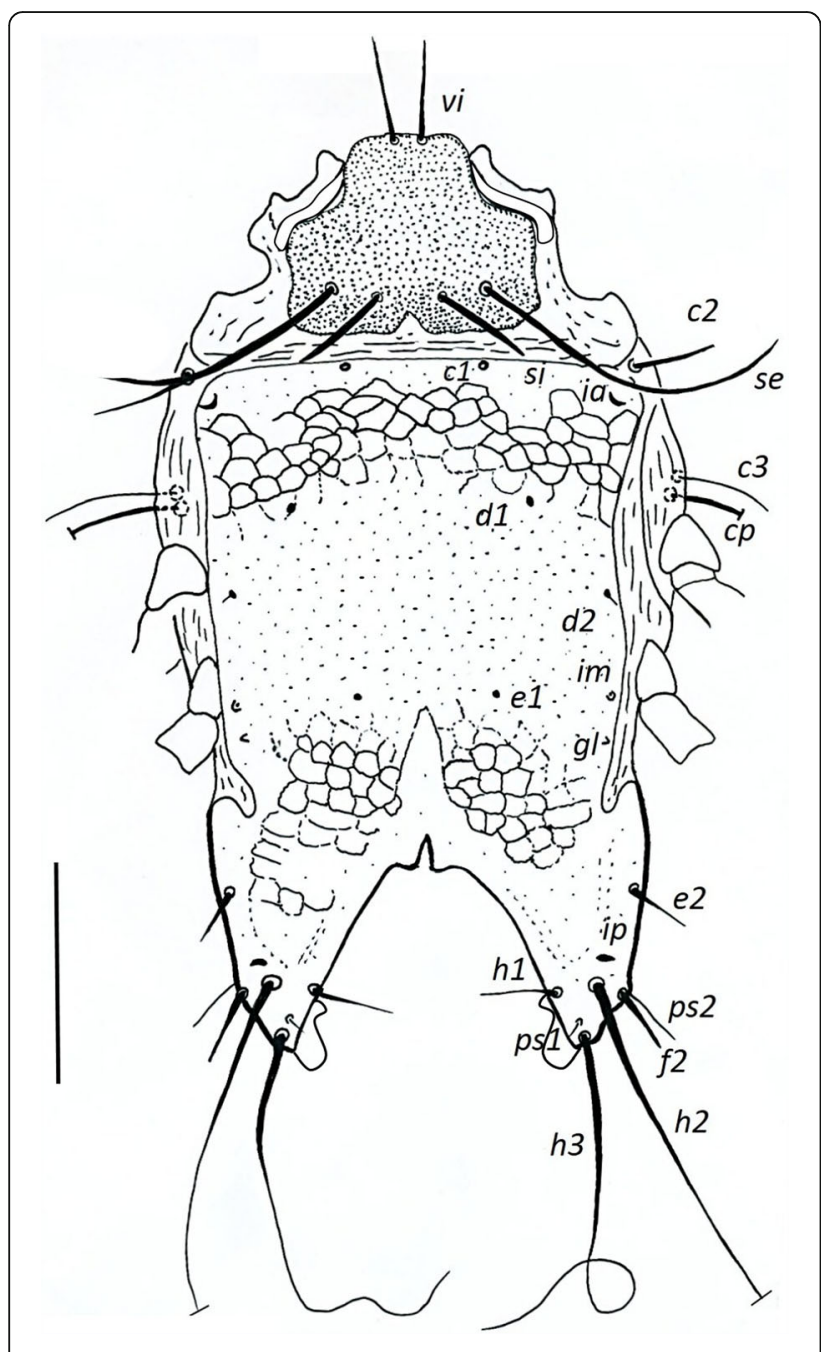

Fig. 1 Gabucinia delibata (Robin), male dorsum (scale bar, $100 \mu \mathrm{m}$ )

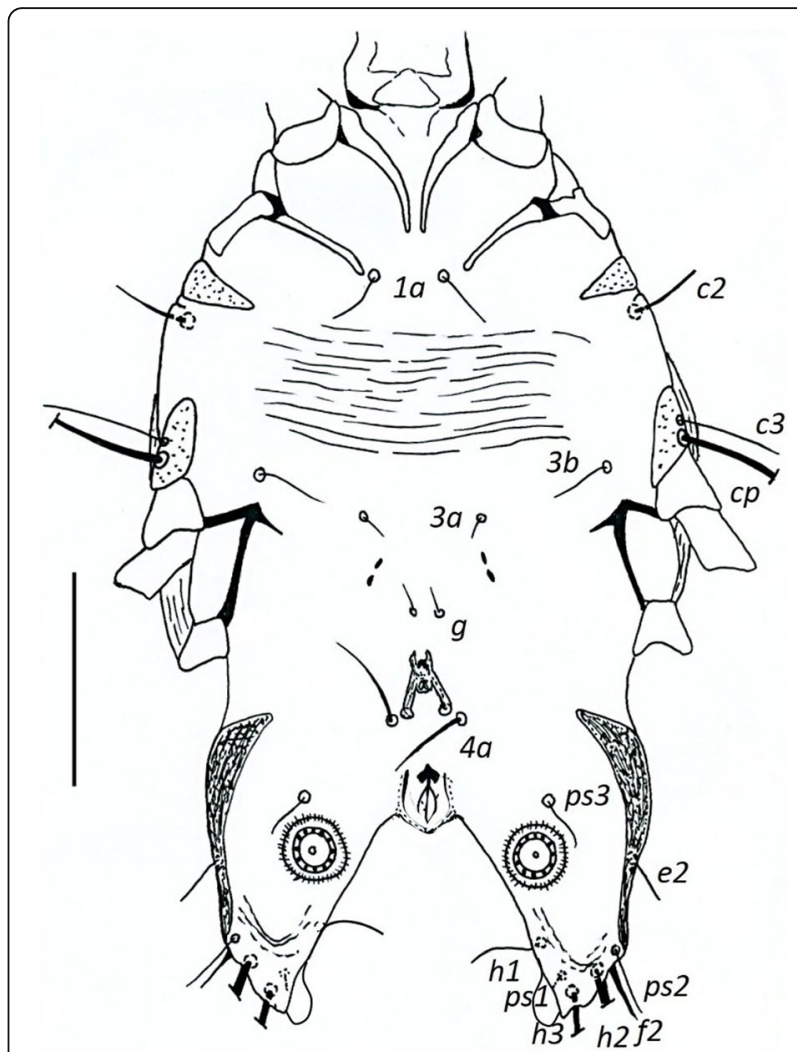

Fig. 2 Gabucinia delibata (Robin), male venter (scale bar, $100 \mu \mathrm{m}$ )

it worth presenting a morphological redescription of this newly recorded mite species from Egypt.

\section{Materials and methods}

During a field survey of ectoparasites infesting birds at Minia Governorate, mite specimens were collected from two individuals of C. cornix birds. Birds were captured using ground nets. The presence of mites was determined through visual examination under a stereoscopic microscope. Mites were collected either by using fine forceps or by cutting a part of infested feather(s). Collected mites were preserved in $70 \%$ ethanol, and then brought to the senior author at Assiut University for identification. Mite specimens were mounted in Hoyer's medium and examined under a phase contrast microscope (BH-2, Olympus, Japan). Measurements are given in micrometers $(\mu \mathrm{m})$. Pencil drawings were made using a drawing tube (camera lucida) attached to the microscope. The voucher materials were deposited in the Acari collection at the Department of Plant Protection, Faculty of Agriculture, Assiut University (FAAU), Egypt for future investigations.

\section{Results}

Family Gabuciniidae Gaud and Atyeo, 1974 
Genus Gabucinia Oudemans, 1905

Gabucinia delibata (Robin, 1877)

\section{Description}

MALE ( $n=1)$-Dorsum (Fig. 1): Idiosoma length 425 (from anterior edge of prodorsal shield to tips of opisthosomal lobes), idiosoma width 240. Prodorsal shield with slightly curved lateral margins, posterior margin with a median notch, surface uniformly punctured, length along midline 85, width 120. Setae vi 37, si 35, se 160 long. Distance between bases of prodorsal setae: vi-si 77, si-se 9, $s e-s e$ 36. Setae si slightly at posterior level to setae se. Scapular shields narrow. Humeral shields present, setae $c 3$ filiform, 37 long and $c p 95$ long, both situated ventrally. Distance between prodorsal and hysteronotal shields 18 . Setae $c 1$ minute, $c 228$ long, on integument close to the anterior margin of hysteronotal shield. Hysteronotal shield entire, anterior margin slightly straight, small lateral incisions present at the base of opisthosomal lobes, length along midline 318, greatest width 192, surface punctured and with polygonal reticulations anteriorly and at base of opisthosomal lobes. Cupules ia, im, ip and hysteronotal glands $g l$ present on hysteronotal shield. Setae $d 1$ and $e 1$ indistinct. Setae $d 2$ minute, $e 226$ long. Supranal concavity

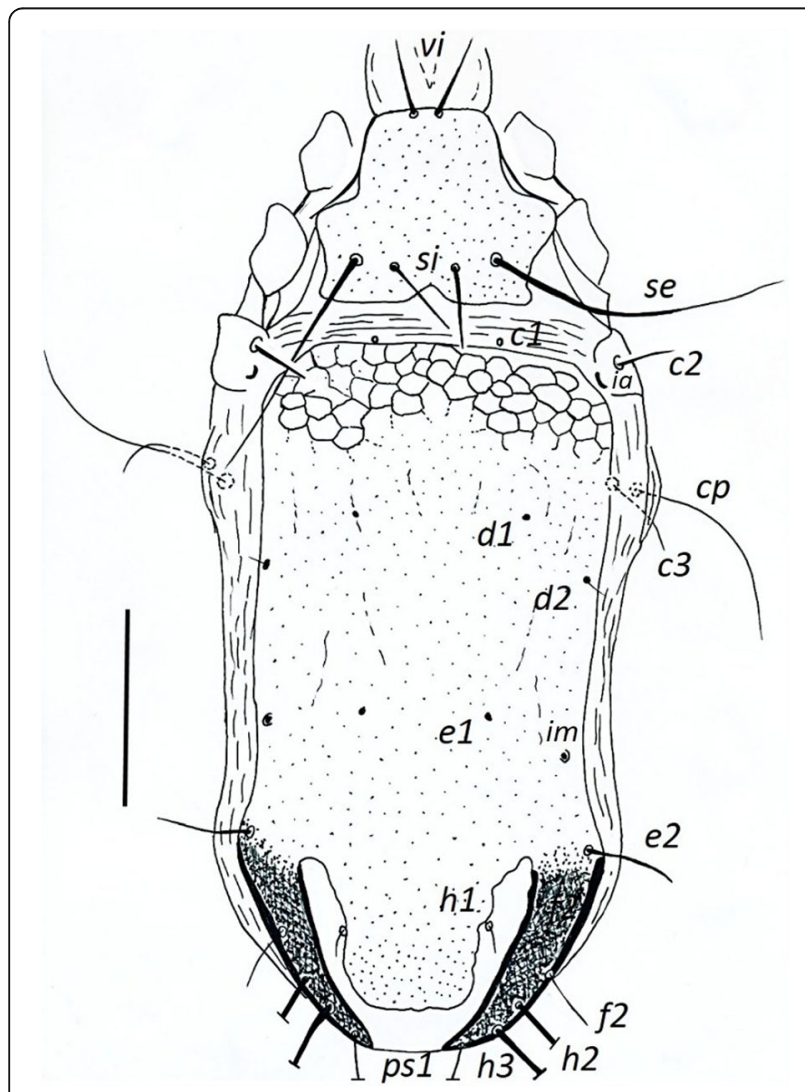

Fig. 3 Gabucinia delibata (Robin), female dorsum (scale bar, $100 \mu \mathrm{m}$ )

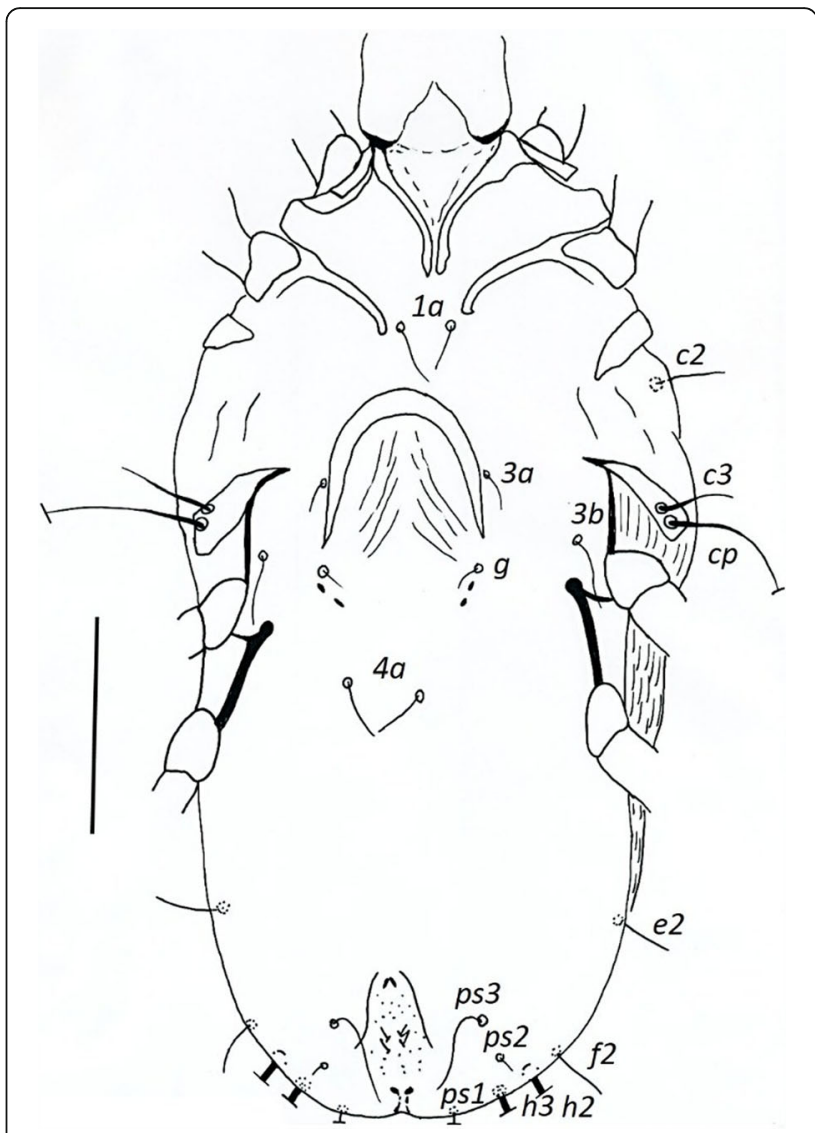

Fig. 4 Gabucinia delibata (Robin), female venter (scale bar, $100 \mu \mathrm{m}$ )

with median projection anteriorly and open posteriorly into terminal cleft. Setae $h 130, h 2182, h 3205$, and f2 28 thickened. Setae ps1 short and spiculiform. Distance between dorsal setae: $c 1-d 160, d 1-d 258, d 2-e 168, e 1-e 2$ 95, h1-h1 110, h2-h2 142, h3-h3 131.

Venter (Fig. 2): Setae 1a filiform, 32 long. Ventral integument smooth, without sclerotized fragments. Genital arch shaped as inverted V, 30 long, 27 wide. Setae $4 a 35$ long, close to posterior tips of genital arch. Adanal shields absent. Epimerites IVa present but very short. Setae ps 231 long. Setae ps3 anterior to adanal suckers, 16 long. Diameter of adanal suckers 25, distance between centers of discs 97. Setae $3 a$ at posterior level to setae $3 b$ alike setae $g$ to genital papillae. Distance between bases of ventral setae: $1 a-3 a 112,3 a-g$ 34, $g-4 a$ 45, 4a-ps3 52, ps3-ps3 105.

Legs (Fig. $5 \mathrm{a}-\mathrm{d}$ ): Seta $c G$ on genu I filiform. Lengths of solenidia: $\omega 1$ of tarsus I 17, $\omega 3$ of tarsus I 40, $\omega$ of tarsus II 15. Setae $d$ at midlength of tarsus IV.

FEMALE ( $n=1)$-Dorsum (Fig. 3): Idiosoma length 520 , idiosoma width 265. Prodorsal shield relatively as in male, length along midline 108, greatest width 138 . Scapular setae si and se approximately at same level. Setae vi 43, si 50, se 180 long. Distance between bases of prodorsal 


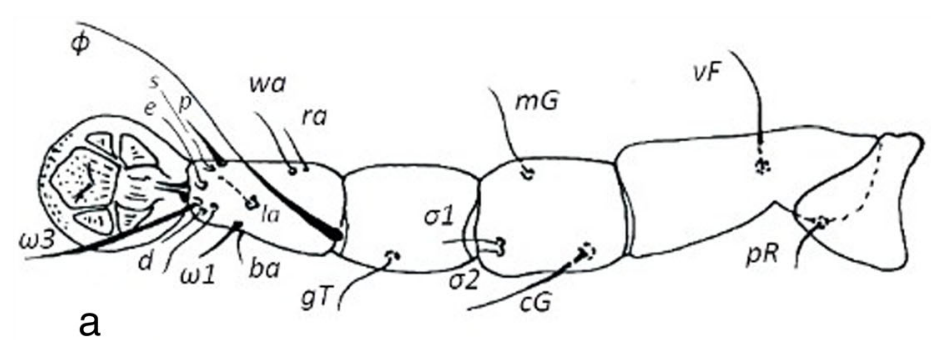

a

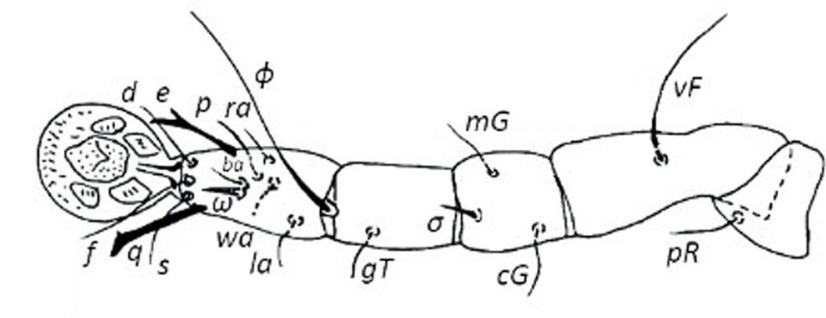

b
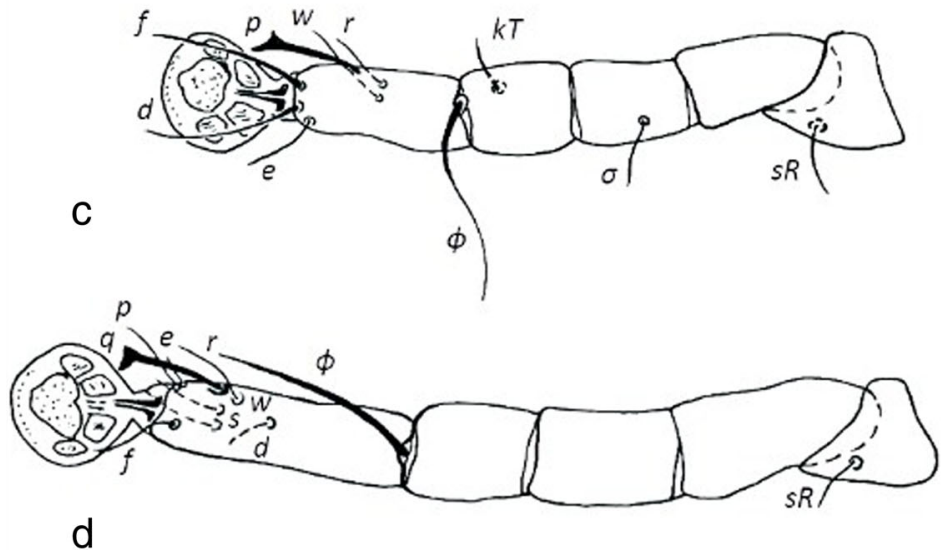

d

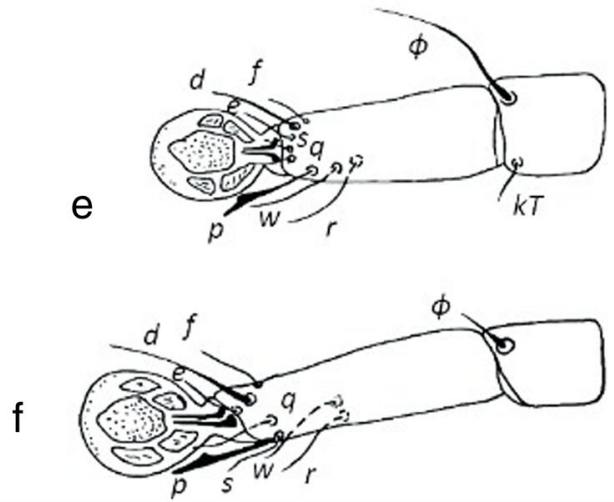

Fig. 5 Gabucinia delibata (Robin): a-d legs I-IV in male (scale bar, $100 \mu \mathrm{m})$; e-f tibia and tarsus of legs III-IV in female (scale bar, $50 \mu \mathrm{m})$

setae: vi-vi 13, si-si 39, se-se 75 . Humeral shields present. Setae $c 3$ filiform, 30 long and $c p 118$ long. Distance between prodorsal and hysteronotal shields 18 . Hysteronotal shield with anterior margin straight, posterior part with
U-shaped unsclerotized area holding setae $h 1$, length along midline 372 , greatest width 215 , surface punctured and with polygonal reticulation anteriorly, cupules $i a$ and im present. Distance between dorsal setae: $c 1-d 1$ 82, $d 1-$ 
$d 247, d 2-e 1$ 90, e1-e2 87, e2-h1 73, h1-h1 83, f2-f2 150, h2-h2 98, h3-h3 55.

Venter (Fig. 4): Epigynum thickened, bow-shaped, 76 long, 80 wide. Setae $3 a$ situated adjacent to epigynum and closer to tips than base. Setae $3 b$ at posterior level to setae $3 a$. Setae $g$ situated between epigynum free tips and genital papillae. Distance between bases of ventral setae: $1 a-$ 3a 87, 3a-g 70, g-4a 80, 4a-ps3 185, ps2-ps3 18.

Legs (Fig. 5e, f): Tarsus IV extending beyond posterior end of opisthosoma, 95 long. Tibia III with setae $\phi 49$ long.

\section{Material examined}

Hooded crow, Corvus cornix, Minia city, Egypt (4; $\left.2{ }^{\lambda}\right)$; 15 February 2010; coll. H.M.H. and A. Abdelhady.

\section{Remarks}

Gaud and Atyeo (1974) depicted opisthosomal lobes in males covered with subtriangular shields separated from hysteronotal shield (see Figure 9b, pg. 545); however, in the current specimens and other specimens collected from Canada and Poland (personal communication with Heather Proctor), only one hysteronotal shield covers the whole body. Also, Gaud and Atyeo (1974) depicted prodorsal shield with deep incisions laterally connected to bases of setae se, while absent in the present specimens. These differences may be considered as intraspecific variations. Gabucinia delibata is worldwide in distribution, with some records as follows: USA (Jones Jr., 1968), France (Gaud \& Atyeo, 1974), India (Kapoor \& Kaur, 1975), Switzerland (Mironov, 1997), Canada and Poland (personal communication with H. Proctor), Slovakia (Zamec \& Fenda, 2012), and Egypt (present study).

\section{Discussion}

The present study reports the feather mite G. delibata for the first time in Egypt. Unfortunately, this study describes the mite species based on a very few numbers of specimens, bearing in mind that crows carry lots of mite individuals. This is because crows are notoriously wary and smart making difficulties in catching in addition to not stress or harm the examined birds. Also, Zamec and Fenda (2012) reported G. delibata from the same bird host in Slovakia. Faunistic and taxonomic studies of feather mites in the Middle East region are inadequate due to the very limited numbers of high-level taxonomists. Moreover, there is a quite insufficient understanding of the ecological traits and distributional patterns of these mites. Taxonomic studies of feather mites in the Middle East region are limited (Aksin, 2007; Negm et al., 2013, 2018, 2019; Rassouli, Darvishi, \& Lima, 2016; Shereef \& Rakha, 1981; Zaher \& Rakha, 1981) and with more focus on domesticated birds rather than wild bird hosts.

\section{Conclusion}

The new mite record reported in the present study provides descriptive information for future taxonomic research of feather mites in Egypt. The large number of unknown species to be discovered in the Middle East region emphasizes the need for more faunistic studies. Hopefully, this work would encourage more comprehensive surveys of feather mites not only in Egypt, but also in the whole region.

\section{Acknowledgements}

The authors would like to greatly thank Drs. Sergei Mironov and Fabio Hernandes for their helpful comments and review. Special thanks to Prof. M. M. H. Kandeel for sincere help in providing relevant literature and to Arwa Abdelhady for help with mite collection.

\section{Funding}

Not applicable.

\section{Availability of data and materials}

Permanent slides of the examined mites are deposited and available in the Acari collection at the Department of Plant Protection, Faculty of Agriculture, Assiut University (FAAU), Egypt.

\section{Authors' contributions}

$\mathrm{HMH}$ contributed to the sample processing and extraction. MWN contributed to research guide and manuscript preparation. Both authors read and approved the final manuscript.

Ethics approval and consent to participate

Not applicable.

\section{Consent for publication}

Not applicable.

\section{Competing interests}

The authors declare that they have no competing interests.

\section{Publisher's Note}

Springer Nature remains neutral with regard to jurisdictional claims in published maps and institutional affiliations.

\section{Author details}

'Department of Plant Protection, Faculty of Agriculture, Assiut University, Assiut 71526, Egypt. ${ }^{2}$ Department of Plant Protection, Faculty of Agriculture, Minia University, Minia, Egypt.

Received: 19 December 2018 Accepted: 1 April 2019

Published online: 29 April 2019

\section{References}

Abd-Alla, A. A. (1993). Studies on Mites Inhabiting Wild Birds, MSc thesis, Al-Azhar University (p. 223).

Aksin, N. (2007). Freyana anatina (Koch, 1844) feather mites (Acarina, Freyanoidea) recorded for the first time on wild ducks (subfamily, Anatinae) in Turkey. Türkiye Parazitoloji Dergisi, 31(4), 302-305.

Canestrini, G., \& Kramer, P. (1899). Demodicidae und Sarcoptidae. Das Tierreich, 7, 1-193.

De Alzuet, A. D. B., Cicchino, A. C., \& Abrahamovich, A. H. (1988). Consideraciones taxonómicas y relaciones hospedatorias de los géneros Coraciacarus Dubinin 1956, Piciformobia Gaud y Atyeo 1975 y Capitolichus Gaud y Atyeo 1975 (Acari, Astigmata, Gabuciniidae), con descripción de tres nuevas especies. Revista de la Asociación de Ciencias Naturales de Litoral, 19, 49-67.

El-Bishlawy, S. M., \& Oyoun, L. M. (1989). Occurrence of feather mites on some domestic birds in the farm of faculty of agriculture at Giza (Egypt). Annals of Agricultural Science, Moshtohor (Egypt), 27(2), 1321-1324.

Galloway, T. D., Proctor, H. C., \& Mironov, S. V. (2014). Chapter 5. Chewing lice (Insecta: Phthiraptera: Amblycera, Ischnocera) and feather mites (Acari: 
Astigmatina: Analgoidea, Pterolichoidea): Ectosymbionts of grassland birds in Canada. In H. A. Cárcamo, \& D. J. Giberson (Eds.), Arthropods of Canadian grasslands (volume 3): Biodiversity and systematics part 1. Biological survey of Canada, (pp. 139-188).

Gaud, J. (1958). Acariens plumicoles (Analgesoidea) parasites des oiseaux du Maroc II. Analgidae. Bulletin de la Société de Sciences naturelles et physiques du Maroc, 38, 27-49.

Gaud, J. (1978). Acariens sarcoptiformes plumicoles des oiseaux Coraciiformes d'Afrique I. Parasites des Meropidae. Revue de Zoologie Africaine, 92, 1023-1052.

Gaud, J. (1983). Acariens Sarcoptiformes plumicoles des oiseaux Falconiformes d'Afrique. I. Introduction: Parasites des Falconidae, des Pandionidae et des Elanions. Revue de Zoologie Africaine, 97, 721-736.

Gaud, J., \& Atyeo, W. T. (1974). Gabuciniidae, famille nouvelle de sarcoptiformes plumicoles. Acarologia, 16, 522-561.

Gaud, J., \& Atyeo, W. T. (1996). Feather mites of the world (Acarina, Astigmata): the supraspecific taxa. Annales du Musee Royal de l'Afrigie Central, Sciences Zoologiques, 277, 1-193.

Gaud, J., \& Till, W. M. (1961). Suborder Sarcoptiformes. In F. Zumpt (Ed.), The arthropod parasites of vertebrates in Africa south of the Sahara (Ethiopian Region). Volume I (Chelicerata), (pp. 180-352). Johannesburg: Publications of the South African Institute of Medical Research, No L (Vol. IX).

Jones Jr., J. (1968). Some parasites of the common crow, Corvus brachyrhynchos Brehm, from Ohio. The Ohio Journal of Science, 68, 25-31.

Kapoor, V. C., \& Kaur, P. (1975). Mite ectoparasites of birds in Punjab, India. International Journal of Acarology, 1(1), 21-26. https://doi.org/10.1080/ 01647957508683733.

Mahgoob, A. E. A., Tharwat, M. E., Kilany, S. O., \& Hafez, T. S. (2006). Mite fauna associated with some domestic and wild agricultural animals and their habitat in Egypt. Arab University, Journal of Agricultural Sciences, Ain Shams University, 14(1), 475-490.

Mazyad, S. A. M., Morsy, T. A., Fekry, A. A., \& Farrag, A. M. M. K. (1999). Mites infesting two migratory birds, Coturnix coturnix (quail or simman) and Sturnus v. vulgaris (starling or zarzuur) with reference to avian zoonosis. Journal of the Egyptian Society of Parasitology, 29(3), 745-761.

Mironov, S. V. (1996). Feather mites of the passerines in the North-West of Russia. Parazitologiya, 30, 521-539 (In Russian with English summary).

Mironov, S. V. (1997). Contribution to the feather mites of Switzerland with descriptions of five new species (Acarina: Sarcoptiformes). Bulletin de la Société Entomologique Suisse, 40, 455-471.

Mironov, S. V., \& Galloway, T. D. (2003). Two new feather mites (Acari, Astigmata) from the turkey vulture Cathartes aura in Canada. The Canadian Entomologist, 135, 655-667. https://doi.org/10.4039/n03-002.

Mironov, S. V., Literak, I., Sychra, O., \& Capek, M. (2014). Two new species of the feather mite family Gabuciniidae (Acariformes: Pterolichoidea) from wrens (Passeriformes: Troglodytidae). Acta Parasitologica, 59(4), 568-579 https://doi. org/10.2478/s11686-014-0287-2.

Mironov, S. V., Proctor, H. C., Barreto, M., \& Zimmerman, J. (2007). New feather mites of the family Gabuciniidae (Astigmata: Pterolichoidea) from New World raptors (Aves: Falconiformes). The Canadian Entomologist, 139, 1-21. https:// doi.org/10.4039/n07-001.

Mohamed, A. A. (1994). Studies on Mites Associated with Birds in Egypt and Yemen. MSC Thesis, Ain Shams University, Egypt (p. 205).

Morsy, T. A., Mazyad, S. A., \& Younis, M. S. (1999). Feather and nest mites of two common resident birds in two ecologically different Egyptian governorates. Journal of the Egyptian Society of Parasitology, 29(2), 417-430.

Negm, M. W., Hernandes, F. A., Nasser, M. G. E.-D., Al Ahmad, A. M., \& Shobrak, M. (2019). New records of feather mites (Astigmata: Analgidae, Avenzoariidae, Proctophyllodidae) from the blackcap, Saunders's tern and osprey in Saudi Arabia. International Journal of Acarology. https://doi.org/10.1080/01647954.2018.1561752.

Negm, M. W., Mohamed, A. A., El-Gepaly, H. M. K., \& Abdelaziz, S. M. (2018). Mesostigmata mites (Acari: Parasitiformes) associated with birds and their nests from Egypt. Turkish Journal of Zoology, 42, 722-731. https://doi.org/10. 3906/zoo-1801-24.

Negm, M. W., Nasser, M. G., Alatawi, F. J., Al Ahmad, A. M., \& Shobrak, M. (2013). Feather mites of the genus Zachvatkinia Dubinin, 1949 (Astigmata: Analgoidea: Avenzoariidae) from Saudi Arabia: A new species and two new records. Zootaxa, 3710(1), 61-71. https://doi.org/10.11646/zootaxa.3710.1.4.

Oudemans, A. C. (1905). Acarologische aanteekeningen XV. Entomologische Berichten, 1, 207-210.

Proctor, H. C., Zimmerman, G., \& Meyer, K. (2006). A new feather mite, Aetacarus elanoides sp. n. (Acari: Gabuciniidae), from the Swallow-tailed Kite Elanoides forficatus (Linnaeus) (Falconiformes: Accipitridae; Perninae). Zootaxa, 1252, 37-47. https://doi.org/10.11646/zootaxa.1252.1.2.

Rakha, M. A. (1980). Taxonomical and Biological Studies on some Astigmatid Mites of Birds. PhD dissertation, Cairo University (p. 417).

Rakha, M. A., \& Mohamed, M. I. (1980). A new raphignathid mite Raphignathus niloticus sp. n. from house sparrow nests in Egypt (Actinedida: Raphignathidae). Zagazig University, Faculty of Agriculture, Research Bulletin No. 206 (pp. 1-6).

Rassouli, M., Darvishi, M. M., \& Lima, S. R. (2016). Ectoparasite (louse, mite and tick) infestations on female turkeys (Galliformes, Phasianidae. Meleagris gallopavo) in Iran. Journal of Parasitic Diseases, 40(4), 1226-1229. https://doi.org/10.1007/ s12639-015-0657-1.

Shereef, G. M., \& Rakha, M. A. (1981). Four new species of feather mites in Egypt (Acaridida: Analgidae). Bulletin of the Zoological Society of Egypt, 31, 77-86.

Shoker, N. I., Tawfek, N. G., Ibrahim, M. H., \& Osman, E. S. (2001). Mites associated with some birds in El-Minia Governorate, Upper Egypt. Egyptian Journal of Biology, 3(2), 100-102.

Zaher, M. A., \& Rakha, M. A. (1981). Microlichus passerinus sp. n. (Epidermoptidae: Acaridida) from Passer domesticus niloticus, in Egypt. Bulletin of the Zoological Society of Egypt, 31, 135-137.

Zamec, R., \& Fenda, P. (2012). New records of feather mites (Acari, Astigmata) from Slovakia. Folia Faunistica Slovaca, 17(3), 257-259.

\section{Submit your manuscript to a SpringerOpen ${ }^{\circ}$ journal and benefit from:}

- Convenient online submission

- Rigorous peer review

- Open access: articles freely available online

- High visibility within the field

- Retaining the copyright to your article

Submit your next manuscript at $\boldsymbol{\nabla}$ springeropen.com 